\title{
Carbonate sediments from Maui bay (coral coast, Fiji) reflect importance of coral reef conservation
}

\author{
Ronick S. Shadrack $^{\mathrm{a}, 1, *}$, Susanne Pohler ${ }^{\mathrm{b}}$, Leo X.C. Dutra ${ }^{\mathrm{a}, \mathrm{c}}$, Krishna Kumar Kotra ${ }^{\mathrm{d}, * *}$ \\ ${ }^{a}$ School of Marine Studies, Faculty of Science Technology and Environment, The University of the South Pacific, Laucala Campus, Fiji \\ ${ }^{\mathrm{b}}$ Institut fuer Erdwissenschaften, Heinrichstr. 26, Graz, 8010, Austria

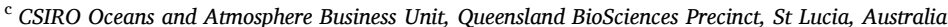 \\ ${ }^{\mathrm{d}}$ School of Biological and Chemical Sciences, Faculty of Science Technology and Environment, The University of the South Pacific, Emalus Campus, Port Vila, Vanuatu
}

\section{A R T I C L E I N F O}

\section{Keywords:}

Maui bay MPA

Grain size

Sediment composition

Coral reef

Fringing reefs

\begin{abstract}
A B S T R A C T
This study describes the origin and characteristics of unconsolidated coral reef sediments from Maui Bay (Coral Coast, Viti Levu Island, Fiji), a site declared under customary law as Marine Protected Area (MPA) by traditional owners in Tagaqe village since the year 2000. Sediment samples were collected from five transect lines and analysed in the laboratory through drying process and sieving to fractional sizes. The results show that sediments from Maui Bay MPA are composed of very coarse sand (mean sediment size of $1.5 \mathrm{~mm}$ ) mostly constituted of coral fragments (e.g. Seriatopora spp. and Porites spp.; coral fragments in $\geq 50 \%$ of grains) followed by other smaller particles of calcareous organisms (foraminifera and molluscs, 10-36\% of the grains). As expected, siliciclastic sediments are most abundant near the mouth of a creek which brings in sediments from the mountainous hinterland. A comparison of Maui Bay with a non-protected fringing reef with very similar bathymetry at Tabua Sands (qualitative data) along the Coral Coast shows that the non-protected site is rich in brown algae with mostly dead corals. The darkish colour and smell of rotten eggs emanating from sediments collected at Tabua Sands suggests anoxic conditions at shallow sediment depth. This is in contrast to the clean white sediments encountered at Maui Bay indicating healthier coral reefs, which shows the importance and success of protection measures implemented here.
\end{abstract}

\section{INTRODUCTION}

Sediment analyses help elucidate sources and fate of sediments generated in terrestrial, coastal and marine areas. Such analyses support a broad understanding about risks and vulnerability of coastal ecosystems such as coral reefs to erosion and accretion processes, and changes in energy patterns of residual waves over the reef flat (Milliman, 1974). Current threats to coral reefs include a mix of direct anthropogenic and climate change effects that work synergistically (Wooldridge et al., 2017). In the Pacific region, direct anthropogenic impacts are often associated with coastal development activities such as land-use change, urbanisation and poor land management practices, as well as over-fishing and coral diseases leading to increase in sediment, nutrient and chemical runoff from farms and settlements into the reefs, tourism related impacts (e.g. anchor damage, trampling) (Dutra et al., 2018).
Marine protected areas (MPAs) involve the use of different management measures according to specific objectives for the area. MPAs are often established into zoned areas with different protective measures (e.g. complete exclusion of fishing activities, seasonal closures, permitted and non-permitted resources) for a number of reasons including economic resources, biodiversity conservation and species protection (Kelleher, 1999). The zones are given specific condition for accessing resources. The measures to achieve MPA objectives are adopted at different levels of society from community level to the government, including international organisations and industry to safeguard the use of resources and preventing exploitation of resources and destruction of concerned resources from anthropogenic activities (Kelleher, 1999).

Anthropogenic impacts on coastal areas are currently a global concern. A study conducted by Gelcich et al. (2014) on public

\footnotetext{
* Corresponding author. United Graduate School of Agricultural Sciences, Kagoshima University, 1Korimoto, Kagoshima, 890-0056, Japan.

$* *$ Corresponding author.

E-mail addresses: rspenly@gmail.com (R.S. Shadrack), krishna.kotra@usp.ac.fj (K.K. Kotra).

1 Present address: United Graduate School of Agricultural Sciences, Kagoshima University, 1-21-24 Korimoto, Kagoshima, 890-0056, Japan.
} 
awareness, concerns and priorities about anthropogenic impact on marine environments revealed that the level of concern about the impacts is closely associated with informedness while, pollution and overfishing are two priorities to be addressed in policy and regulatory frameworks by policy makers. Understanding impacts of management actions on coral reefs cannot be fully understood based solely on conventional ecosystem indicators, such as abundance of fish and invertebrate, live coral and benthic cover through visual surveys (Ford et al., 2018). Instead, such understanding requires a better understanding about ecosystem processes. Sediment analyses quantifies and identify grains which provide evidence for natural or anthropogenic impacts by identifying the sources and tracing the origin of sediments in a coastal coral reef setting (Milliman, 1974). Sediment analyses may add insight into the effects of pollution which is important to incorporate on coral reef conservation planning and monitoring programs.

Anthropogenic threats have been exacerbated by climate change impacts (e.g. increase in sea surface temperature, changes in ocean chemistry, extreme weather events, sea level rise) which are already causing negative impacts on coral reef communities in the Pacific (see review by Dutra et al., 2018; also Brown et al., 2017, Elsner et al., 2008, Guillemot et al., 2010, Hoffmann, 2002, Kench et al., 2018, Lockwood et al., 2012, Maata and Singh, 2008, Nott and Walsh, 2015). Sediment analysis methods require simple technology, are relatively inexpensive and are able to determine sources of sediment delivered into coastal ecosystems. Consequently, they provide useful insights into coastal dynamics and connectivity (Janßen et al., 2017; Perry et al., 2017). Sediment analyses can complement visual census data and add to the most critical aspect of the coral reef assessment and monitoring program.

This study will demonstrate the importance of conserving coral reefs through analysis of sediment size and composition including support from literature.

\subsection{Research context}

South Pacific coral reefs provide a variety of ecosystem services that include providing shelter and habitats for biodiversity, act as breeding grounds for fishes and invertebrates and prevent coastline erosion by reducing wave energy and supplying sediment to the beaches (Chin et al., 2011; Fisher et al., 2015). The natural beauty of reef ecosystems is a major reason for tourist attraction to tropical coastlines thus generating important income for the national economy of many Pacific Island Countries and Territories (PICT) (Pascal and Seidi, 2013), especially when socio-cultural and environmental issues are considered together (Tyllianakis et al., 2019). However, coastal coral reefs in the Pacific are degrading due to the synergistic effects of climate and non-climate drivers (see above). In response to these threats Fiji has established a large network of Community Conservation Areas (CCA), which are a form of managed area under local customary fishing jurisdictions (Tyllianakis et al., 2019; Sloan and Chand, 2016).

Fiji is an Archipelago of 330 islands and over 1000 reefs (Quinn and Kojis, 2008) encompassing a coral reef area of over $30,000 \mathrm{~km}^{2}$ (Sloan and Chand, 2016). The largest continuous reefs are found in the two largest island, Viti Levu and Vanua Levu, where a $100 \mathrm{~km}$ reef (reported to be the largest) occurs along the Coral coast of the Southern Viti Levu (Spalding et al., 2001). The reefs are diverse including Fringing, barrier, platform, oceanic, ribbon and drowned reefs (Sykes and Morris, 2009), and contains high biodiversity of over 350 species (Lovell and Maclardy, 2008).

Fiji is a global coral exporter accounting for approximately $10 \%$ of corals in international trade over the period of 2000-2010 (Wood et al., 2012) and is the leading exporter of coral in the Pacific region (Cumming et al., 2002). Fijian coral reefs have an average live coral cover of 45\% (range 8-60\%) (Morris and Mackay, 2008) and are remarkably resilient to sudden catastrophic events (Sykes and Lovell, 2009). The general status of Fiji's coral reef has been changing in the last two decades, with widespread coral bleaching events recorded in 2000 and
2015-16 (Cumming et al., 2000; Mangubhai, 2016), degraded reefs in the proximity of major urban centres (Dutra et al., 2018; Lal et al., 2018), localised destruction due to acute impacts, such as cyclones (Mangubhai, 2016). Overall reefs recover following disturbance events (Chin et al., 2011), where reefs subjected to pollution and overfishing are slower in the recovery process (Zann, 1994). Some coastal fringing reefs exhibit signs of degradation due to pollution and overfishing driven by coastal development and population growth (Chin et al., 2011; Veitayaki and Ledua, 2016; Bell et al., 2017).

The integrated local threats to Fijian coral reefs exhibit $34 \%$ low threats; $24 \%$ medium threats and high level of threats for $21 \%$ of reefs and very high level for $10 \%$ of reefs (Burke et al., 2011). In 2017 Fiji received more than 842,000 visitors, spending over $\mathrm{F} \$ 1.9$ billion (US $\$$ 890.3 million) across the industry, employing approximately 118,500 Fijians. The industry contributed approximately $40.3 \%$ towards the Fiji's Gross Domestic Product (GDP). The coral coast of Viti Levu has long been an area of major tourist activity (Shah, 2008) where sixteen percent of all tourists visiting Fiji in 2017 stayed in this area (Ministry of Industry Trade and Tourism, 2018).

Coral reefs in Viti Levu are exposed to overfishing while sediment damage were assessed as a high threat (Sykes and Morris, 2009). Two thirds of Fiji reefs are being threatened by local activities such as overfishing. Other threats to Fiji's coral reefs include cyclones, coral bleaching and predator outbreak (Cumming et al., 2002). The aforementioned threats have prompt the government and the local communities to developed management strategies that aim to promote the protection of the coral reef biodiversity and increase benefits from the resources.

Locally Managed Marine Areas (LMMA) are examples of CCA implemented in Fiji covering about $30 \%$ of the Fijian inshore area, spanning its 330 islands over an area of over $30,000 \mathrm{~km}^{2}$ (Sloan and Chand, 2016). LMMA combine elements of both formal Marine Protected Areas (MPAs) and sacred (tabu) areas (Tyllianakis et al., 2019), are either permanent or temporary "no-take" reserves, where fishing and other marine harvesting is prohibited (Veitayaki et al., 2004). The LMMA network model for marine conservation combines the traditional system of community-based coastal management and modern management systems, with the caveat that such approaches need to be contextualized in the different governance regimes across the Pacific Ocean (Aswani et al., 2017). Under the Fiji Fisheries Act Section 13, the jurisdiction of the group with customary rights to qoliqoli is recognised and given effect. This provision gives the customary right holders the legislation to be consulted before granting inshore permits to any harvester wishing to gain entry to the qoliqoli (Techara and Toniak, 2009). The decision to any harvester is to be decided at first in the community level before permit approval from the local government. Additionally, the Environmental Management Act was implemented on January 1, 2008 and this act provides inter, alia, the environment assessment and the approval for development activities. This act sets powerful provisions for the assessment of the environmental impacts of coastal development on MPAs. The indicators of success for MPAs include species, habitat health and wellbeing of the community. Techara and Troniak (2009), reported that in June 2007, 385 marine and 25 freshwater qoliqoli contributed to livelihood of about 400,000 customary land owners in Fiji and about half of the qoliqoli owners are now part of FLMMA including the Maui Bay MPA. The communities registered under the Fijian LMMA network may choose to establish strict no take zones (tabu) within their qoliqoli.

Maui Bay is part of the LMMA Network of the Tikina Korolevu-i-Wai where permanent no-take MPAs were established (Fig. 1) in front of Namada village to the West and Votua-lailai and Votua village to the East. The aforementioned sites impress the visitor with the richness of living coral cover, including micro-atolls composed of Porites spp., Staghorn corals (Acropora spp) and small branching corals such as Seriatopora spp.

Branching corals which are fast growing and fragile contribute large amounts of coarse sediment to the reef flat's sediment budget (Janßen 


\section{Map of study site}
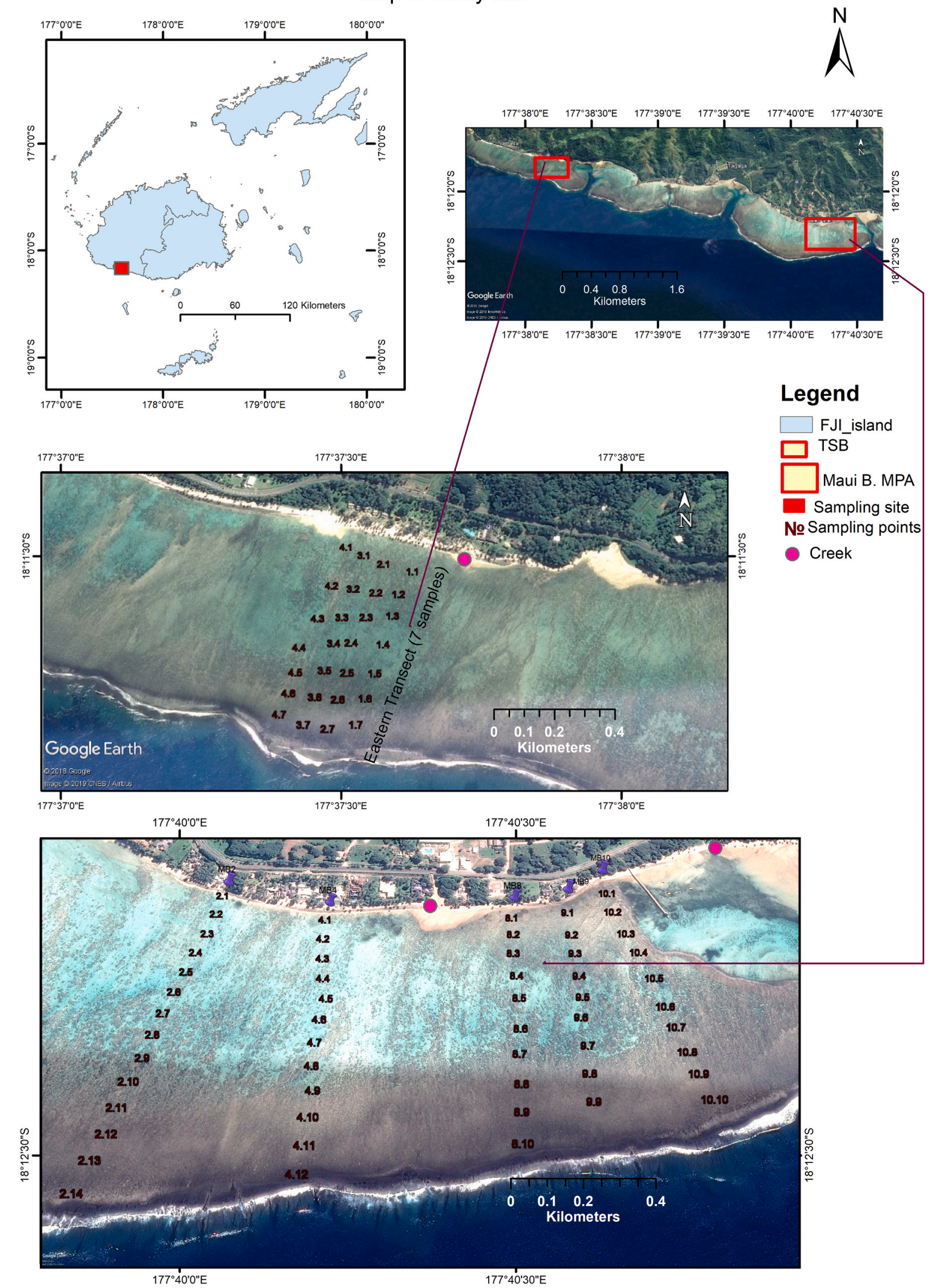

Fig. 1. Study area in the Fiji Islands (top right) and the study sites such as TSB and Maui Bay shown on the top right. The center image is TSB and the area where 7 samples are collected along the Eastern Transect, and 3 transect to the West and the bottom image is Maui Bay MPA with the 5 sampling benchmarks (source: Google Maps, and Esri -WGS, 1984). 
et al., 2017). In contrast, many other fringing reefs along the Coral Coast have reef flats which appear to be degraded with many dead or partly dead Porites micro-atolls, dead branching corals and lack or very low abundance of living Staghorns or small branching corals, even farther out to sea (L.X.C. Dutra and S. Pohler, pers. Observations (2003-2019); see also Bonaldo et al., 2017; Clements et al., 2012 on comparisons between MPA and non-MPA areas around Maui Bay). While some of these reef flats are very shallow with little accommodation space for large corals, other areas such as Maui Bay have a relatively deep nearshore area and shallow reef crest. Also Tabua Sands Beach (TSB), just to the east of Namada village has this type of bathymetry. Among a number of reasons for reef degradation the problematic of water quality and over-fishing have been particularly addressed in Fiji's Coral Coast (Mosley and Aalbersberg, 2003; Taloiburi, 2009; Bonaldo et al., 2017). The gaps in toxicology studies (Varea et al., 2020) and effects of micro plastics in the marine environment (Dehnm et al., 2020) is also a concern for coral reef conservation initiatives. Consequently, the integrity of coral reefs is important for these reasons including tourism benefits, ecosystem services and protection of coastline (Farber, 1987; Harris et al., 2018) with flow-on benefits to livelihoods in coastal communities.

Previous studies of unconsolidated marine sediments have been carried out in Fiji to assess the potential of mineral deposits (Knedler and Glasby, 1985), to characterise and re-construct existing and palaeo environments (Srinivasan and Kennette, 1981; Roy, 1988; Sharma, 2007; Morrison et al., 2018), to improve cement manufacture processes (Morris et al., 2003), assess the impacts of cyclones (Kostaschuk et al., 2003; Terry et al., 2008; Etienne and Terry, 2012), heavy metal pollution (Maata and Singh, 2008) and identify evolutionary processes of reef platforms (McKoy et al., 2010). Conventional indicators of coral reef health include abundance of fish, invertebrates and live coral cover. This information is very general and may not be suitable to adequately assess coral reef status and health (Ford et al., 2016) as it does not consider the substrate which forms the basis for calcareous green algae, seagrass and platform settlement of young coral. Thus, this paper aims to highlight the importance of including sediment characterization into coral reef conservation and monitoring program as an addition to the exercise to coral reef survey. Basic sediment analysis studies are present in Fiji and in the South Pacific in general, however, the application of such knowledge to coral reef management initiatives in Fiji are missing.

Maui Bay coral reef lies on the Queens' Road East of Sigatoka. The beach front contains small villas and bungalows built by private owners, mostly from overseas. On the east and central part of the MPA are two creeks. Although the surrounding creeks and resorts may cause concern, harmful activities such as wastewater disposal into the backreef, appear to be minimal. Maui Bay MPA has a village representative who watches over the coral reef and enforces the customary rules. Tabua Sand Beach (TSB) is located close to Tabua Village. A resort was built near the coastline with white sandy beaches which attract tourists. A small creek enters the fringing reef near the resort. Locals and visitors are frequently seen wading, gleaning and fishing in the backreef area and there does not seem to have any kind of control on these activities. No MPA or reserved zones are established, and although no qualitative data has been collected the coral reef ecosystem seems to be more degraded when compared to Maui Bay, with relative high abundance of algal turf spp and Chlorodesmus spp which may indicate overfishing of herbivore fish and nutrification (Bonaldo and Hay, 2014; Smith et al., 2015).

It is hoped that this study will help elucidate important questions related to the impacts of sea level rise, catchment and coastal development of coral reefs. To do so, we identified and quantified the main carbonate and non-carbonate grains and their size fractions in sediments from an MPA located in Maui Bay and compared results with sediments from a nearby-unprotected site (Fig. 1). The interpretation of results is discussed with regards for the applicability of the methodology in supporting management initiatives in Fiji.

This paper is divided into four sections, first, the introduction which covers the general discussion on the background of the study area and also explain Marine protected areas and the context for Fiji, the issues affecting coral reef conservation and management, the current survey methods, and then the outline of our research context. Section two covers the methods used, site description, and the laboratory procedures for sediment analysis. Section 3 presents the results of the sediment grain size distribution and composition of the Maui bay coral reef with description of TSB fringing reef. Finally, in section four, the grain size and composition are discussed followed by a qualitative comparison of non-protected site (TSB) and protected site (Maui Bay coral reef MPA), and a general discussion on the importance of supporting sediment analysis to management.

\section{Materials and methods}

\subsection{Study area and sample criteria}

Maui Bay is located on the South Western side of Viti Levu, NadrogaNavosa province, Fiji (Fig. 1). Maui Bay is a development site with holiday villas at the Coral Coast, which is bordered seawards by fringing coral reefs which extend 600-800 m seawards and stretch from East to West over $2400 \mathrm{~m}$. The shallow fringing coral reef complex is terminated by a narrow $40 \mathrm{~m}$ wide passage to the East and a wide $150 \mathrm{~m}$ wide passage to the West; all is included within the MPA (Bosserelle et al., 2016). The back reef area is relatively shallow (1.5 m on average and at low tide) bounded East and West by an algal ridge and to the South by the reef crest, both of which are exposed at low tide. These morphological features effectively form a rim around the $1.4 \mathrm{~km}^{2}$ large lagoon so that during low tide the area becomes cut-off from the open ocean (Bosserelle et al., 2016). Inside the lagoon, there are patches of coral communities more abundant towards the reef crest growing close to mean sea level. The habitat map prepared by Bosserelle et al. (2016, Fig. 1 and unpublished data) indicates that live coral cover inside the lagoon is interspersed with seaweed and occasional seagrass habitats alternating with sandy and gravelly patches. Parallel to the coastline is beach rock exposed (2988-3380 years old) which formed during the higher sea level stand in the mid-Holocene (Stanley, 2007; Bosserelle et al., 2015, 2016). This feature is partially submerged during high tide. The beach behind the beach rock is a perched beach that is not reached by fair weather waves. Ten benchmarks (BM 1-10) separated $50 \mathrm{~m}$ from each other were previously demarcated in Maui Bay as part of the WACOP (Waves and Coast of the Pacific, http://gsd.spc.int/wacop) project funded by the European Union (Bosserelle et al., 2016). The present study used five benchmarks (BM 2, 4, 8, 9 and 10) to collect sediment samples (Fig. 1) in $50 \mathrm{~m}$ distance from each other.

The TSB is located about $5 \mathrm{~km}$ to the West of Maui Bay near Namada village (Fig. 1). A small creek enters the fringing reef near the resort's main building and it impresses the observer with the abundance of green algae growing in it. Other creeks in the vicinity did not show this density of algae, which may indicate eutrophic waters, the source of which is unclear, but could be from an agricultural area and fish ponds upstream. The reef in front of the TSB appears degraded with few patches of living Porites spp. and branching corals left, even further out to sea. An abundance of Ceraesignum maximum (formerly Dendropoma) was observed inhabiting nearshore massive Porites colonies (Fig. 7). This vermetid gastropod is considered a pest in aquariums and maybe an indicator organism for reef degradation in the wild. The vermetids feed with mucus nets which can cover surrounding corals and cause partial mortality (Zill et al., 2017). The creeks at both sites are continuously flowing into the lagoon at low discharge rates. However, in the wet season from October to April, the creeks increase in flow velocity and deposit material from the land into the coral reef lagoon.

\subsection{Sediment composition analysis}

Sediment samples were principally collected from within the MPA site of Maui Bay and a few from the non-protected fringing reef site in 
front of TSB during a passing visit by one of the authors (S.P.) in order to compare the composition of sands from the two areas at least in a preliminary way. Sediment samples in Maui Bay MPA were collected in April 2013 (T 2 and 4) and in April 2015 (T. 6, 9, 10) with 10-14 samples from each benchmark (depending on length of transect). Sediment samples were collected by hand along benchmark transects lines at intervals of $50 \mathrm{~m}$. Approximately $1000 \mathrm{~g}$ were collected per sample and stored in plastic bags. A geographical positioning system (GPS) receiver (Garmin e-Trex 10) was used in the field to geo-locate the sampling points. Wet samples were kept in the deep freezer prior to processing. In the laboratory, samples were submerged in fresh water to remove salts. Sediment was allowed to settle before decanting water and dried in the oven at $105 \mathrm{C}^{\circ}$ over night (Heiri et al., 2001), then weighted, and sieved using the following fractions: $16 \mathrm{~mm}, 8 \mathrm{~mm}, 4 \mathrm{~mm}, 2 \mathrm{~mm}, 1 \mathrm{~mm}, 0.500$ $\mathrm{mm}, 0.250 \mathrm{~mm}, 0.125 \mathrm{~mm}, 0.063 \mathrm{~mm}$ and the pan. The sieve shaker was operated electrically to have vertical and horizontal tapping actions with spring-loaded tie rods with a 10 min shaking operation. The sediments are classified under the following three categories according to their size fraction: gravel, sand and silt/mud (Bowron et al., 2009) (Table 1). The dry-weight retained after sieving was recorded in electronic spreadsheets. Lithology composition was analysed for the fractions $>4 \mathrm{~mm}$ (combined $8 \mathrm{~mm}$ and $16 \mathrm{~mm}$ fractions) down to $125 \mu \mathrm{m}$ using a light microscope. One hundred grains were counted based on the method of Johnsson et al. (1993), and each of the fractions were identified under a stereomicroscope and appropriate observations, such as counting and description were noted under the following categories: (i) coral fragments, (ii) other calcareous bioclasts and biomorpha, (iii) rock fragments (from carbonate rocks), (iv) siliciclastic grains (non-carbonate, e.g. quartz or other silicate minerals), and (v) non-identified grains (Table 1). These categories followed the scale proposed by Milliman (1974).

\section{Results}

\subsection{Sediment grain size}

Half of the sediments from Maui Bay MPA are characterized as coarse sand (Table.1), whereby the mean sediment grain size is $1.5 \mathrm{~mm}$ (blue line in Fig. 2). Coarse sand ( $1 \mathrm{~mm}$ ) made up $35 \%$ of the sediments while gravel contributes $15 \%$ to the overall sediments from the Maui Bay MPA (Fig. 2). On average, at $350 \mathrm{~m}$ from the shoreline a larger grain size is found (approximately $1.8 \mathrm{~mm}$ ) while towards shoreline and the reef crest, the average grain size is reduced to coarse sand size $(>1.0 \mathrm{~mm})$ (Fig. 4a and b). The higher mean grain size is shown as "peaks" in Fig. 4a (at $250 \mathrm{~m}, 350 \mathrm{~m}$, and $450 \mathrm{~m}$ ). The "peaks" are often in the vicinity of micro-atolls (circular colony of coral, dead on top but living around the perimeter) which have a "halo" of staghorn corals growing on them. These are shedding coral branches which account for the coarseness of

Table 1

Grain size categories used in the analysis (Blott and Pye, 2001).

\begin{tabular}{|c|ll|}
\hline \multicolumn{2}{|c|}{ Prain Size } & \multicolumn{2}{c|}{ Description } \\
\hline-4 & 16 & Coarse \\
-3 & 8 & Medium \\
-2 & 4 & Fine \\
-1 & 2 & Very Fine \\
0 & 1 & Very coarse sand \\
1 & 500 microns & Coarse \\
2 & 250 & Medium \\
3 & 125 & Fine \\
4 & 63 & Very fine \\
5 & 31 & Very Coarse \\
& & Coarse \\
\hline
\end{tabular}

the sediment. The areas containing finer sediments are the "valleys" depicted in Fig. 4a, characterized by deeper waters (around $1 \mathrm{~m}$ ) subjected to lower wave energy (at $150 \mathrm{~m}, 300 \mathrm{~m}$ ). The fine grains (at 550 $\mathrm{m}, 600 \mathrm{~m}$ ) are subjected to the back wash during low tide and were transported and segregated loosely over the reef crest (Fig. 4a and b). Sediment size decreases from $150 \mathrm{~m}$ to $450 \mathrm{~m}$ towards the shoreline and reef crest respectively. Coarser sediments and finer sediments were abundant on the reef flat and nearshore respectively (Fig. $4 \mathrm{a}$ and b). The mean grain size in the back reef between $250 \mathrm{~m}-400 \mathrm{~m}$ is $1.7 \mathrm{~mm}$, which is coarser when compared to the other reef zones (Fig. 4a and b).The general mean sea level over the Maui Bay coral reef is depicted in Fig. 3, the speed of wave before breaking is around $4 \mathrm{~m} / \mathrm{s}$ with the annual average wave height of $2.15 \mathrm{~m}$ and after breaking over the reef crest, its velocity reduces to $1 \mathrm{~m} / \mathrm{s}$ and wave height to $30 \mathrm{~cm}$ (Bosserelle et al., 2015). On the reef flat (the whole area from shoreline to reef crest), the mean grain sizes are between $1.3 \mathrm{~mm}$ and $1.1 \mathrm{~mm}$ and at the shoreline is around $0.7 \mathrm{~mm}$ (Fig. $4 \mathrm{a}$ and b.). Hence the grain sizes on the reef flat and back reef areas are relatively coarser when compared to the shoreline (Fig. $4 \mathrm{a}$ and b.). Finer grains are more abundant in benchmarks 8 and 10 closer to the creek's outlet (Fig. 1). The sediment grain size between benchmarks showed, benchmark 4 has the highest mean grain size compared to benchmark 10 with the least (Fig. 5). There is a high variability from the mean of grain size in benchmark 8 and 10 (Figs. 1 and 5).

In TSR, half of the sediment mean grain size sampled on the eastern transect ( 7 samples) are characterized as medium sand (Table 1) where the mean sediment grain size is $0.8 \mathrm{~mm}$ (Fig. 10). Coarse sand makes up about $30 \%$ of the grain while gravel makes up $20 \%$ of the grain size distribution (Fig. 10).

\subsection{Sediment composition}

In Maui Bay, analyses showed that corals and their fragments supply most ( $\geq 50 \%$ of grains) of the sediments sampled in all 5 benchmark transects (Fig. 6). Although present in all samples, siliciclastics (mostly quartz grains and rock fragments) are most abundant in benchmarks 2 and 9. Other calcareous organisms including forams and molluscs are the second most abundant grains which make $10-36 \%$ of the grains in the sampled transects (Fig. 6). Other calcareous organisms (foraminifera, mollusc, etc.) are more abundant (36\%) in transects of benchmark 4 than any other benchmark. Benchmark 10 has the highest percentage of corals and rock fragment (Fig. 6). The four samples collected from TSB differ in some respects from those of Maui Bay (Figs. 8 and 9). The sample collected at $300 \mathrm{~m}$ from the shoreline at TSB showed the presence of a fresh coral (arrow pointing) which was recently dead (Fig. 7). The amount of corals and molluscs and most other components is very similar at both sites. Interestingly, the quality of the grains is different, which is not apparent in the grain counts. The grains at TSB are highly abraded or covered with coralline algae crusts which caused problems to grain identification. This problem did not occur with the Maui Bay samples. We also had to introduce two more categories of grain type, the Homotrema, an encrusting red foraminifera which is abundant at TSB and rare at Maui Bay and tubes (calcareous and organic) of various organisms (e.g. polychaetes, molluscs (vermetids) and others of unknown origin). In addition, sediments from Tabua Sands Beach have a sulphur smell (of rotten eggs) and many grains have a greyish colour. The analysis of the composition of grains (7 Samples) in TSB showed that the category organisms supply most $(>50 \%)$ of the sediment in all samples (Fig. 11). Rock fragments were also abundant followed by corals and sciliciclastic grains.

\section{Discussion}

\subsection{Sediment grain size}

Finer carbonate sediments are generated from the outer part of the 


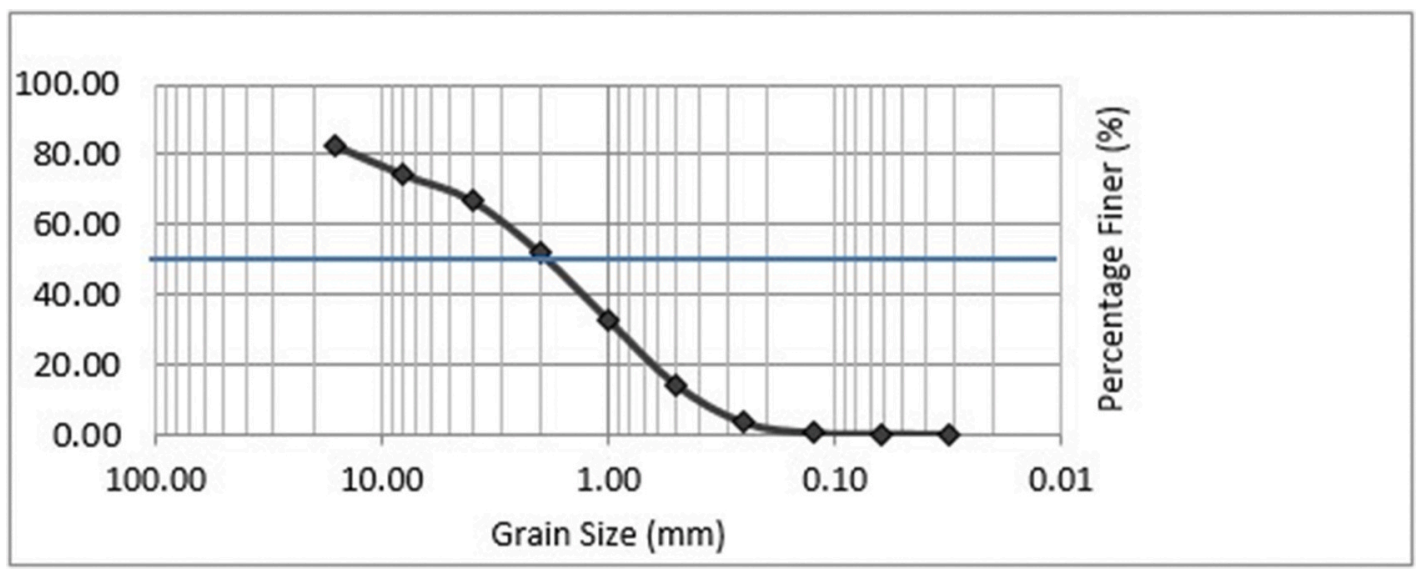

Fig. 2. The distribution of grain size using $\log _{10}$ scale for all transamples collected over the Maui Bay MPA reef flat.

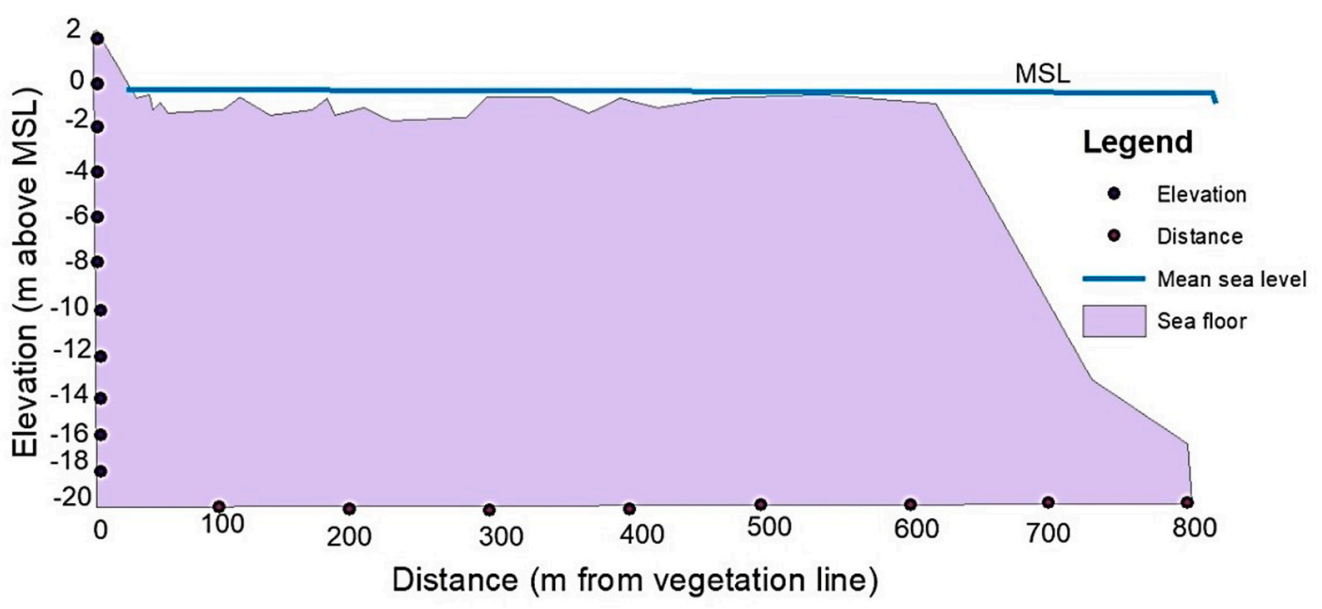

Fig. 3. The elevation above mean sea level (MSL) of the Maui Bay MPA coral reef.

reef and transported to nearshore area (Fig. 4a and b), where they settle due to a low energy environment favoured by the barrier provided by the reef crest. Finer siliciclastic sediments are transported into the beach system by creeks and currents (Fig. 1); similarly, McLaren and Bowles (1985) observed that sediment grain sizes decrease with the direction of the current flow from the source. The combination of coral fragments dominating sediments near the reef crest along with a low energy environment at the back reef and towards the shoreline (Bosserelle et al., 2015) indicates that the Maui Bay reef provides both, the source of sediment and a physical barrier that protects the coastline from erosion by reducing wave energy, which has an effect on sediment transport in this area. Coral reefs play a significant role in the generation of sediments in Maui Bay, their survival and growth is critical for coastal protection and as habitats for fish and invertebrates.

Sediment transport and grain size decreases with the direction of flow of waves and currents (McLaren and Bowles, 1985). Wave action and bioerosion slowly break the coral reef framework, thus producing finer grains that are transported further by waves and currents. Coarser grains remain closer to sources as they need more energy to move while finer grains are easily moved and deposited further towards the shoreline (Dunham, 1962; Parker and Toro-Escobar, 2002). In Maui Bay this is demonstrated by the increase in grain size from around $100 \mathrm{~m}$ from the shoreline (Fig. 4a and b) where at around $250 \mathrm{~m}$ there is another peak in coarser sediments, reaching its highest mean grain size (and therefore energy) at $350 \mathrm{~m}$. In between these "peaks" in sediment grain size are reef pools and crevices in the reef framework, which are filled with finer grains as energy reduces. The consolidated reef substrate is confined to certain zones of the coral reef area where coarser sediments are deposited. This geomorphological feature is probably associated with the lowering sea level that occurred from 5000 years before present (ky BP) and is reported from numerous tropical regions of the world, where reef platforms were filled with sediments (Martin et al. 1979; Baker and Haworth, 2000; Davis et al., 2000; Baker et al. 2001; Martin et al. 2003; Baker et al. 2005; Perry et al., 2017).

In Maui Bay, lowering seas affected the reefs closer to the coastline, which were caught by regressive sand terraces. Lower seas also exposed and truncated reef tops where healthy reefs corals grow at the lower tidal limit maintaining the reef structure thus maintaining an effective barrier against wave action and coastal erosion. Similar to other coastal reefs from around the world (e.g. Leão et al., 1999), under these conditions Maui Bay reefs are now widely governed by external factors such as increasing water agitation and turbidity, and subaerial exposure of their tops during low tides. This situation affects the coral species living in these nearshore reefs, where only the species able to resist occasional sub-aerial exposition and strong variations in salinity and temperature survive (e.g., Porites rus, P. cylindrica, Seriatopora spp). The protection against waves offered by the Maui Bay coral reef complex facilitates the deposition of finer sediments (sands, but excluding mud), especially in the transition between sandy beaches and the back reef (Bosserelle et al., 2016).

The sediment grain size between each benchmark shows the mean of around $1.5 \mathrm{~mm}$ in all benchmarks (Fig. 5). On the eastern side of the Maui Bay MPA (Fig. 1), transect 10 (Fig. 5), there is a high variability of grain sizes which is simply influenced by the wave action through the 


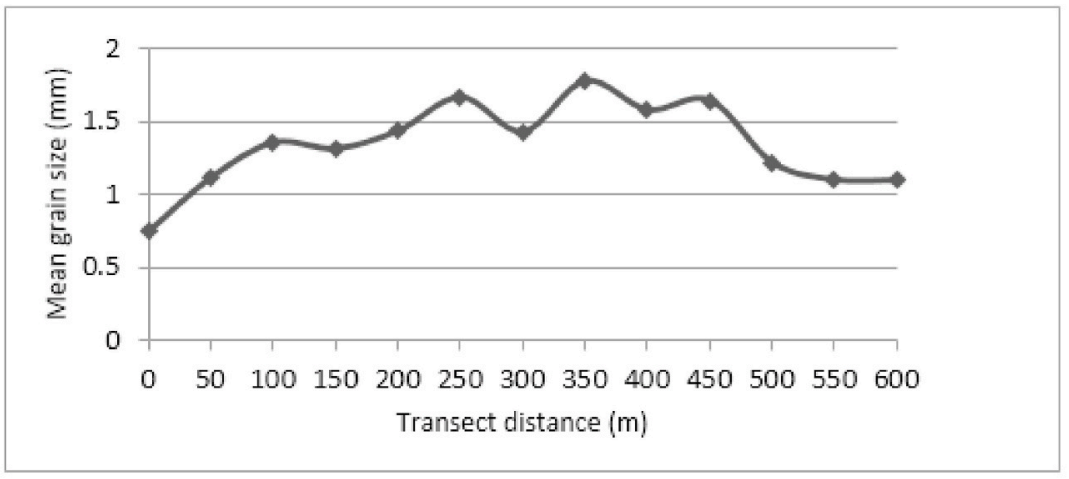

a. Mean sediment grain size among all samples collected along all transects from the shoreline to the reef crest. The distance is starting from shoreline to the reef crest.

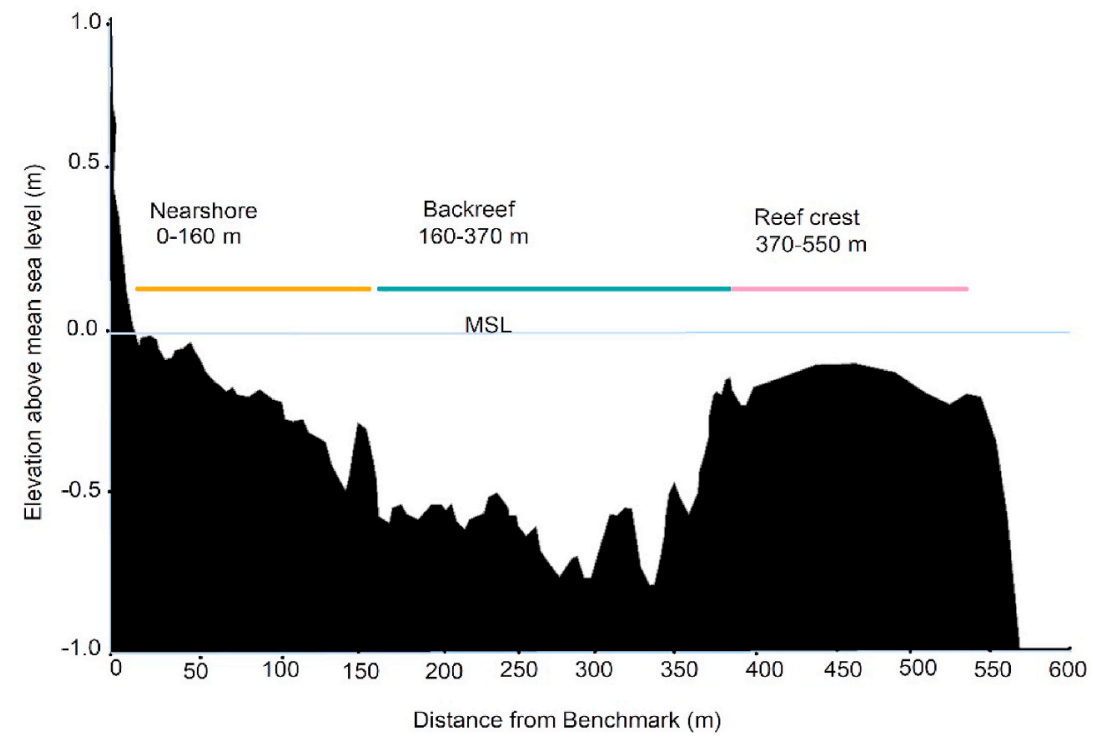

b. Cross section of Benchmark 8 and coral reef zonation in Maui Bay.

Fig. 4. a.) The mean sediment grain size over all transect and, $b$ ) the cross section of the elevation across the reef platform in benchmark 8.

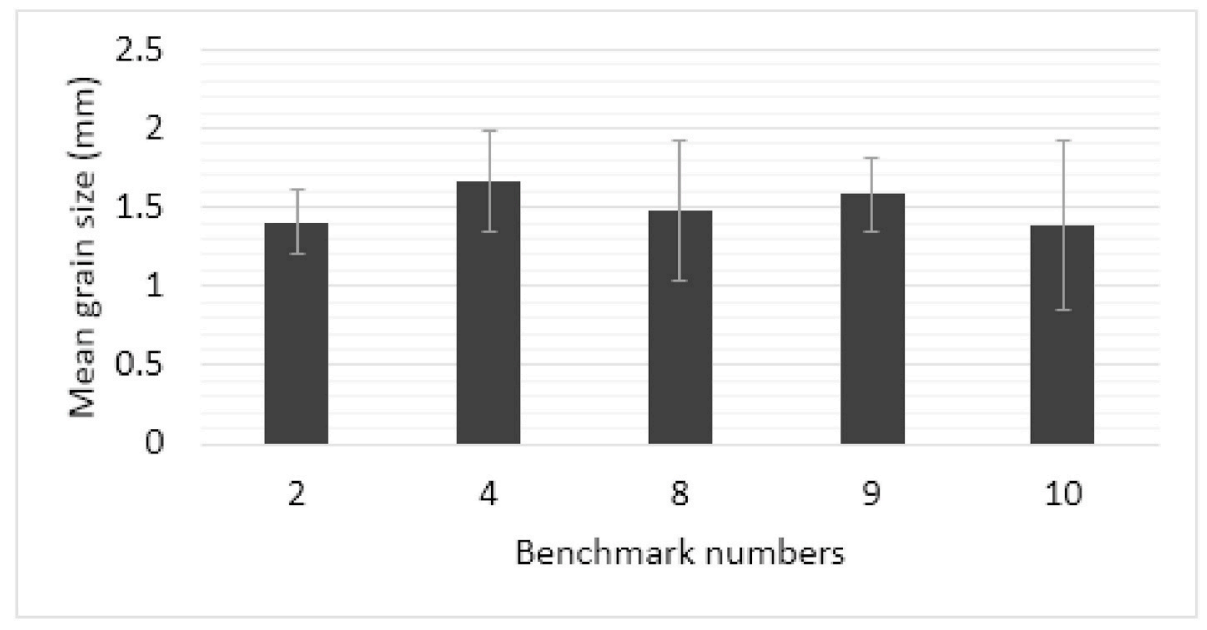

Fig. 5. Mean sediment grain size for each benchmarks in Maui Bay coral reef.

reef groves and the influx of terrestrial sediments from the mainland. Since the wind direction is mostly south east at the location, the surface waves influence the deposition of coarser sediments whereby, the grains size at benchmark 9 and 10 are larger and more consistent (Fig. 5).
Benchmark 4 is a deeper portion of the reef whereby larger grains tend to aggregate at the area either through normal process or through storms, therefore the mean grain size is larger than at all other benchmarks (Fig. 5). The presence of a creek at benchmark 8 has influenced 


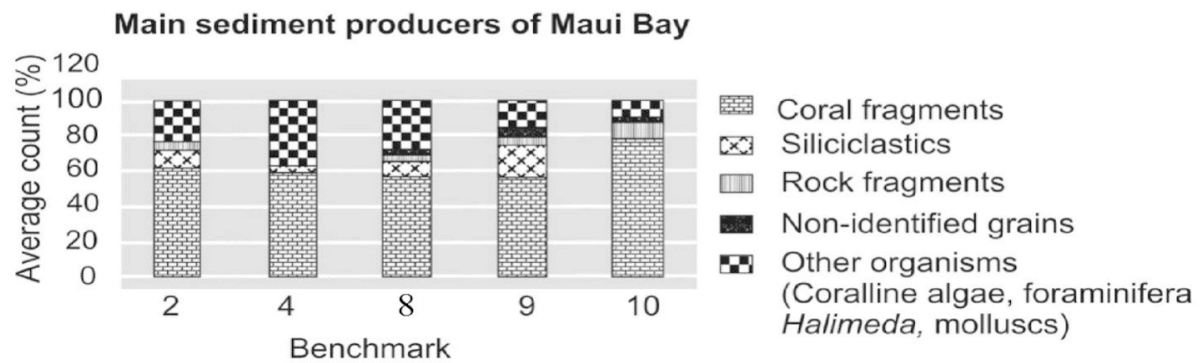

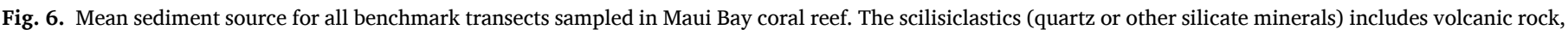
while rock fragments is only from carbonate rock.

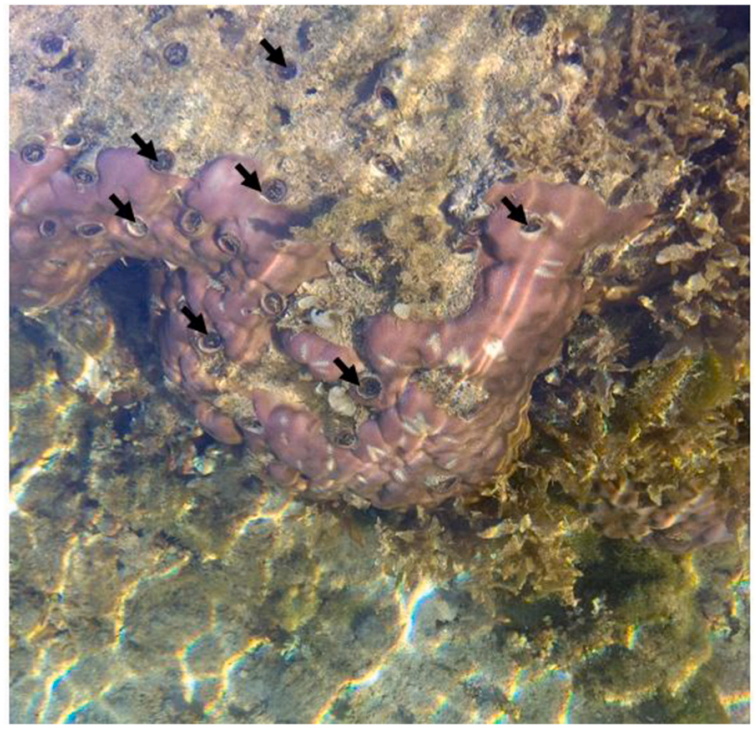

Fig. 7. Massive Porites colony invaded by Ceratosignum maximum (Sowerby) (black arrows). An abundance of fleshy green and brown algae surrounds the colony. Fish bites are seen on the coral. Location is nearshore of Tabua Sand Beach, about $5 \mathrm{~m}$ from shoreline at low tide. (For interpretation of the references to colour in this figure legend, the reader is referred to the Web version of this article.)

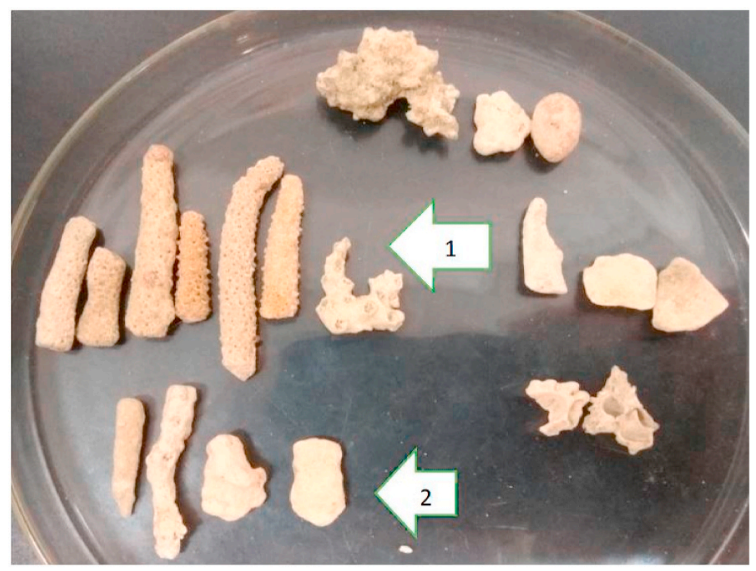

Fig. 8. Coarse $(8000 \mu \mathrm{m})$ fraction of sample MB 9-50 m. Fragments of branching corals (arrow 1) are seen in this image with corallites well preserved and suggesting that fragments were not abraded for a long time. Arrow 2 points to more abraded fragments which appear to be older. Glass dish measures 13 $\mathrm{cm}$ in diameter.

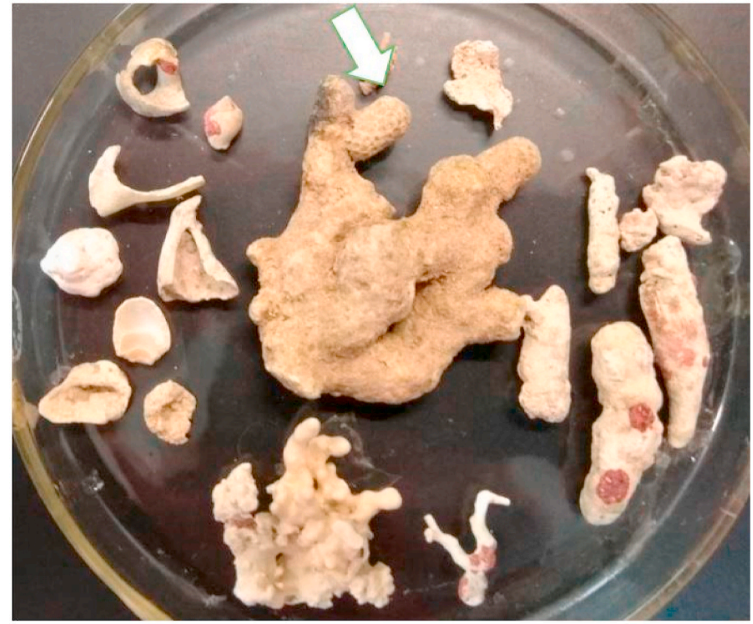

Fig. 9. Coarse $(8000 \mu \mathrm{m})$ fraction of sample TS - $300 \mathrm{~m}$. Coral fragments in this sample are only recognizable by their shape; corallites are obliterated either by abrasion or by overgrowth with a plaque of coralline red algae. Only the large fragment in the middle has a "fresh" looking branch at the tip with preserved corallites. Also frequently seen are incrustations of coral rubble and other reef materials with the encrusting rotaliid foraminifer Homotrema sp. (red patches). Glass dish measures nine $\mathrm{cm}$ in diameter. (For interpretation of the references to colour in this figure legend, the reader is referred to the Web version of this article.)

also the grain size where a high variability is observed almost similar to benchmark 10 (Figs. 1 and 5). Upland activities and influx of creek during storms may have influenced the grain composition here.

\subsection{Sediment composition}

The coarser grain size in a coral reef setting indicate a young reef system in the face of high energy wave regime (Jan $\beta$ en et al., 2017) and along with the fact that corals are the main source of sediments $(\geq 50 \%)$ in the Maui Bay MPA (Fig. 6) suggest in the outset that the Maui Bay coral reef has been providing suitable habitats for animals and plants and also generating sediments thus supporting food chains, and at the same time, protecting the coastline and supplying sediments for beaches (Janßen et al., 2017).

Other calcareous organism such as foraminifera and molluscs were the second most dominant benthic organism that produce sediment in Maui Bay. These organisms were more abundant in benchmark 4 when compared to other transects because this is a deeper area adjacent to the beach where more organisms can live. Nevertheless, further investigation of the presence of foraminiferas in benchmark 4 may help to identify impacts from terrestrial sources like rock weathering and landbased development impacts as some have similar water quality requirement to zooxanthellate corals (Hallock et al., 2003). Our results indicate that the sediments deposited in benchmark 10 are likely to be 


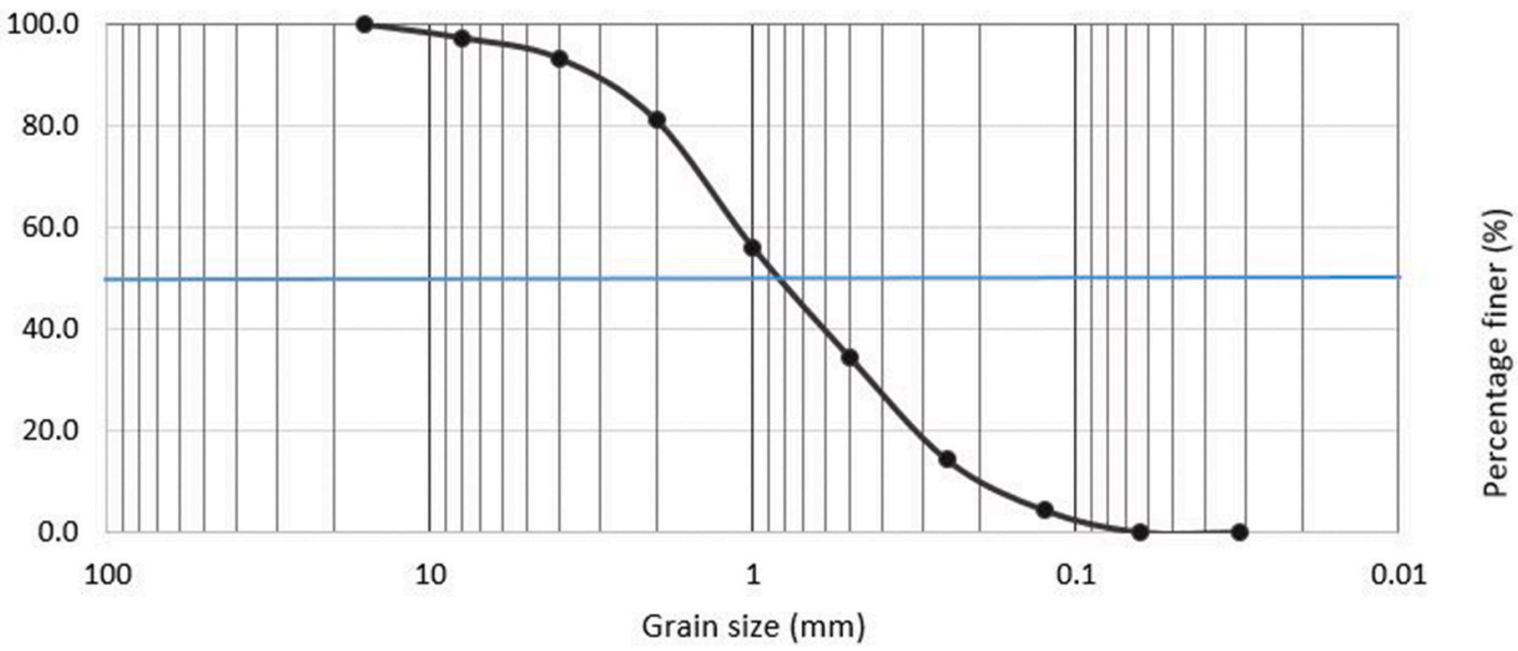

Fig. 10. The distribution of sediment grain size for Tabua Sand Beach using Log10 scale for easterly transect in every $50 \mathrm{~m}$ over $350 \mathrm{~m}$ distance from shoreline.

Main sediment producers of Tabua Sand Beach

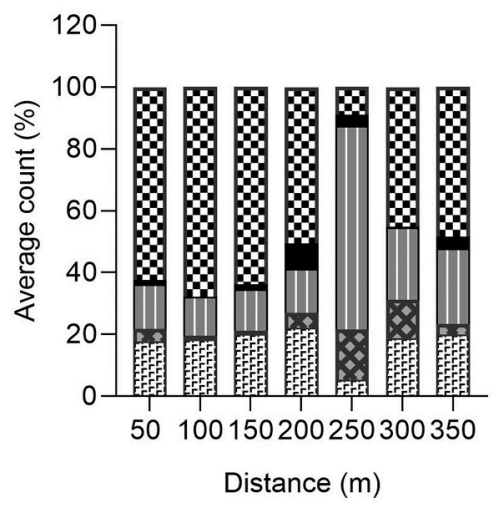

타라 Coral fragments

- Siliciclastics

- Non-identified grains

미 Rock fragments

Other organism (Coralline algae, foraminifera, Halimeda, molluscs)

Fig. 11. Mean sediment source for 7 samples for easterly transect in Tabua Sand Beach Coral reef. The siliciclastics includes volcanic rock, while rock fragments are only from carbonate rock and possibly include coral fragments overgrown with coralline red algae.

driven by the incoming waves from the groove of the reef crest (Fig. 1), which displaces siliciclastic sediments further towards the shoreline. Rock fragments from the old reef platform in benchmark 10 are broken up also due to wave energy and transported towards benchmark 9 where they are deposited (Fig. 6).

There is a sensitive equilibrium between sea level and reef height which is provided by the rate of sea level variability and the rate of carbonate production by corals, coralline algae, foraminifera, etc. The decline of these sediment producing organisms such as coral will prevent reefs to keep up with the rise of sea level, which may impact the economic value of tourism estates and built infrastructure (e.g. houses and roads), and livelihoods. Coral reef degradation will lead to increased coastal erosion as coastlines are exposed to high energy wave regimes, which will affect the capacity of corals to adapt and maintain the reef system to protect the coastline against future climate change effects (Guannel et al., 2016). These results showing that corals are the main sediment producers strongly emphasize the need to reverse the recent trends in coral reef decline in the region as an effective way to mitigate the negative impacts associated with expected sea level rise due to climate change.

\subsection{Comparison with Tabua Sands Resort samples}

The sediment grain size at TSB is finer grains. The rock fragments are abundant which reflects the breaking down of the reef. The high abundance of other organisms such as molluscs, foraminifera showed the importance of these organism to maintain the beach system, however, in the case of TSB, these important organisms are remains from the dead reef system, indicated by their colour and weathering. The samples from TSB were only analysed partially (7 samples along the eastern transect) and a larger survey is planned in the future. However, a few findings from sediment samples from TSB are worth discussing. The sand from TSB had a sulphuric smell when collected and is dark grey already a few centimetres below the water/sediment interface. This was the case for all four sites including the sample collected $350 \mathrm{~m}$ seaward of the shore (Fig. 1). We suggest that high organic influx has led to anoxia below the sediment surface with a resulting activity of anaerobic bacteria which produce $\mathrm{H}_{2} \mathrm{~S}$.

The siliciclastic content at TSR is probably due to the input of sediment from the nearby creek, however, no data were available on the site condition prior to establishment of the resort. The creek is full of green filamentous algae, a potential indicator for nutrient enrichment and sedimentation e.g., Biggs, 2000). The source of the pollutants is unknown but it can be safely assumed that the water enters the reef with its excessive nutrient load.

The corals on the reef flat are mostly dead and overgrown with brown algae (Sargassum sp.). This is the case to at least $350 \mathrm{~m}$ from the shore.

The coral rubble in the sediment samples is worn and overgrown with coralline red algae and encrusting foraminifera. This is probably an 
indication of lengthy residence on the fringing reef floor with reduced influx of newly produced bioclasts and biomorpha. At Maui Bay MPA, live coral is abundant and few brown and turf algae are seen on the reef flat.

Jan $\beta$ en et al. (2017) found that sediments have a short life span of only $60-150$ years in the reef sedimentary system, whereas at Maui Bay it is found that sediments may be reworked from beach rock as old as 4000 years BP (Bosserelle et al., 2016). Harney et al. (2000) studied surficial carbonate sediments from Kailua Bay (Oahu, Hawaii) and dated numerous skeletal constituents using radiocarbon dating. They found that shoreface bioclastic sediments are relatively old (500 yr. BP up to $5000 \mathrm{yr}$. BP) and that coarser bioclastic sediments are younger than finer sediments. The authors suggest a long storage time for skeletal grains on reef flats with grains possibly dating back as far as 6000 to $3000 \mathrm{yr}$. BP when a $+1-2 \mathrm{~m}$ higher sea-level stand prevailed during the mid-to late Holocene. A similar scenario could be envisioned for Maui Bay fringing reef. Detailed radiometric age-dating of sediment components has not yet been conducted neither at MB nor at TSB but could be a suggestion for future research.

\subsection{Importance of sediment analysis to support customary management}

The information generated in this research should be of direct value on Maui Bay CCA and should be considered in the management of other CCAs across Fiji and the Pacific to deal with impacts from coastal development, foster coral reef resilience and prepare for future climate and anthropogenic impacts. The first stage to provide useful information to customary leaders is to provide a synthesis of the current knowledge about drivers of change such as climate, weather condition, overfishing and coastal development (including this and other research in the area combined with traditional knowledge). The synthesis should be developed in a way that is meaningful to decision-makers from both indigenous (itaukei) and government structures (Sloan and Chand, 2016) and can be used to initiate a process to co-develop management objectives and actions to be tailored and implemented to achieve the objectives (Cakacaka, 2008; IUCN, 2009; Clarke and Jupiter, 2010). An effective monitoring program is important to assess the effectiveness of management actions and is part of the Fijian LMMA framework (Tawake and Tuivanuavou, 2004). This study showed that sediment analysis helped identify coral fragments and their abundance in the different size classes in sediments as a potential indicator. Sediment analyses provide a useful and relatively low-cost and straightforward method to monitor changes in the reef. Also important is to develop and maintain a high level of stakeholder engagement and ownership of the process as these have been identified as barriers for effective management of natural resources (Folke et al., 2007; Stocker and Wood, 2012; Dutra et al., 2015). Based on the findings of this study, the information on sediment characteristics of conservation areas are lacking and, this is the first to characterise sediment for MPA sites. Conservation helps to protect coral reef ecosystems from threats of human activities. Apparently as seen in this study, coral and other calcareous organisms outweigh siliciclastic and other materials contained in the sediments to more than $60 \%$ of grains for Maui Bay MPA. Comparison of Maui Bay MPA qualitative analysis of TSB shows that careful monitoring, data collection and conservation measure are needed to enhance knowledge on the impacts of activities along the coastal areas to improve the management of coastal resources.

\section{Conclusion}

The mean sediments of Maui Bay are very coarse sand $(1.5 \mathrm{~mm})$ and are predominantly coral fragments $(>50 \%)$. Other calcareous organisms including foraminifera and molluscs also contribute to sediments in Maui Bay. Larger grains are more abundant where corals abound. The siliciclastic sediments are more abundant where the river enters the lagoon, between benchmarks 4 and 8 , and at 500 m east of benchmark
10. Real estate development and land clearing further upstream may be contributing to siliciclastic and rock fragments to some extent in this area but a later monitoring provided with this baseline study will provide a better conclusion. Such measures must be in combination with existing effective management practices on the reefs which bring together customary and western knowledge systems and stakeholders with a common goal of maintaining the reef to support the provision of ecosystem goods and services.

Our results show the need to implement effective protection and conservation measures to ensure that corals continue to grow and support reef resilience, ecosystem goods and services and livelihoods in the face of coastal development pressures and climate change, as corals and other calcareous organism are main sediment components. One limitation of our study is that using only surface sediment analysis proved to be useful but the method does not allow to measure changes in time. The use of sediment cores and methods to reconstruct the past conditions may provide useful information to support coral reef management and adaptation into the future. As a direction of further research, it is important to understand the changes in sediments with time by collecting sediment cores, live coral and fish population data to better understand links between healthy reef ecosystems and sediments and the effectiveness of the creation of the MPA in Maui Bay.

\section{Declaration of competing interest}

The authors declare that they have no known competing financial interests or personal relationships that could have appeared to influence the work reported in this paper.

\section{Acknowledgement}

This study is part of the RSS postgraduate diploma and was supported by USP-ACIAR (grant number FFIS/2012/074). We acknowledge the following people for their help during the research: Cybrien Bosserelle, for providing support with funding and field work; Robert Jimmy and Chris Barlow (ACIAR project manager) for supporting the postgraduate study; Viliamu Powell, for facilitating the financial processes until the end of this study. We also extend our acknowledgement to European Union for funding the filed work through its WACOP (Wave and Coast of the Pacific) project (grant number: FED/2011/281-131) under the Secrateriate of the Pacific Community (SPC) in Fiji, which finance most of the field work for this study.

\section{References}

Aswani, S., Albert, S., Love, M., 2017. One size does not fit all: critical insights for effective community-based resource management in Melanesia. Mar. Pol. 81, 381-391.

Baker, R.G.V., Haworth, R.J., 2000. Smooth or oscillating late Holocene sea-level curve? Evidence from the palaeo-zoology of fixed biological indicators in east Australia and beyond. Mar. Geol. 163 (1-4), 367-386.

Baker, R.G.V., Haworth, R.J., Flood, P.G., 2001. Inter-tidal fixed indicators of former Holocene sea levels in Australia: a summary of sites and a review of methods and models. Quat. Int. 83, 257-273.

Baker, R.G., Haworth, R.J., Flood, P.G., 2005. An oscillating Holocene sea-level? Revisiting rottnest island, western Australia, and the fairbridge eustatic hypothesis. J. Coast Res. 42, 3-14.

Bell, J.D., Cisneros-Montemayor, A., Hanich, Q., Johnson, J.E., Lehodey, P., Moore, B.R., Pratchett, M.S., Reygondeau, G., Senina, I., Virdin, J., Wabnitz, C.C.C., 2017. Adaptations to maintain the contributions of small-scale fisheries to food security in the Pacific Islands. Marine Policy.

Biggs, B.J.F., 2000. Eutrophication of streams and rivers: Dissolved nutrient-chlorophyll relationships for benthic algae. J. North Am. Benthol. Soc. 19 (1), 17-31.

Blott, S.J., Pye, K., 2001. GRADISTAT: a grain size distribution and statistics package for the analysis of unconsolidated sediments. Earth Surf. Process. Landforms 26 (11), 1237-1248.

Bonaldo, R.M., Pires, M.M., Guimarães, P. R. Jnr, Hoey, A.S., Hay, M.E., 2017. Small marine protected areas in Fiji provide refuge for reef fish assemblages, feeding groups, and corals. PloS One 12 (1), e0170638. https://doi.org/10.1371/journal. pone. 0170638 .

Bosserelle, C., Kruger, J., Movono, M., Reddy, S., 2015. Wave inundation on the coral coast of Fiji. In: Australasian Coasts and Ports Conference 2015: 22nd Australasian 
Coastal and Ocean Engineering Conference and the 15th Australasian Port and Harbour Conference. Engineers Australia and IPENZ, p. 96.

Bosserelle, C., Pohler, S., Lal, D., Reddy, S., Movono, M., Begg, Z., Kumar, S., Krüger, J., 2016. Maui Bay (Fiji), Bathymetric and Topographic Data Collection. South Pacific Community, Fiji, pp. 1-15.

Bowron, T.M., Neatt, N.C., Graham, J.M., Lundholm, J., van Proosdij, D., 2009. Postrestoration monitoring (year 1) of the Lawrence town Lake salt marsh restoration project, 13. CB Wetlands and Environmental Specialists Publication, pp. 1-80.

Brown, C.J., Jupiter, S.D., Albert, S., Klein, C.J., Mangubhai, S., Maina, J.M., Wenger, A. 2017. Tracing the influence of land-use change on water quality and coral reefs using a Bayesian model. Sci. Rep. 7, 4740.

Burke, L., Reytar, K., Spalding, M., Perry, A., 2011. Reefs at Risk Revisited. World Resources Institute.

Cakacaka, A., 2008. Effects before and after Closure of a Marine Protected Area: Case Study of Navakavu, Suva, Fiji Islands. MSc Thesis. The University of the South Pacific.

Chin, A., Lison de Loma, T., Reytar, K., Planes, S., Gerhardt, K., Clua, E., Wilkinson, C., 2011. Status of Coral Reefs of the Pacific and Outlook: 2011. Global Coral Reef Monitoring Network.

Clarke, P., Jupiter, S.D., 2010. Law, custom and community-based natural resource management in Kubulau District (Fiji). Environ. Conserv. 37 (1), 98-106.

Clements, C., Bonito, V., Grober-Dunsmore, R., Sobey, M., 2012. Effects of small, Fijian community-based marine protected areas on exploited reef fishes. Mar. Ecol. Prog. Ser. 449, 233-243.

Cumming, R.L., Toscano, M.A., Lovell, E.R., Carlson, B.A., Dulvy, N.K., Hughes, A. Koven, J.F., Quinn, N.J., Sykes, H.R., Taylor, O.J.S., Vaughn, D., 2000. Mass bleaching in the Fiji islands. In: Proceedings of the Ninth International Coral Reef Symposium, Bali. 23-39 Oct. 2000. M. K. Moosa, S. Soemodihardjo, A. Soegiarto, 2, pp. 1161-1169.

Cumming, R., Aalbersberg, W.G., Lovell, E.R., Sykes, H.R., Vuki, V.C., 2002. Coral Reefs of the Fiji Islands: Current Issue.

Davis, A.M., Aitchison, J.C., Flood, P.G., Morton, B.S., Baker, R.G.V., Haworth, R.J., 2000. Late Holocene higher sea-level indicators from the South China coast. Mar. Geol. 171, 1-5.

Dehm, J., Singh, S., Ferreira, M., Piovano, S., 2020. Microplastics in subsurface coastal waters along the southern coast of Viti Levu in Fiji, South Pacific. Mar. Pollut. Bull. 156, 111239.

Dunham, R.J., 1962. Classification of carbonate rocks according to depositional textures. In: Classification of Carbonate Rocks - A Symposium. AAPG Archives. http://arch ives.datapages.com/data/specpubs/carbona2/data/a038/a038/0001/0100/0108. htm.

Dutra, L.X., Bustamante, R.H., Sporne, I., van Putten, I., Dichmont, C.M., Ligtermoet, E., Deng, R.A., 2015. Organizational drivers that strengthen adaptive capacity in the coastal zone of Australia. Ocean Coast Manag. 109, 64-76.

Dutra, L.X.C., Haywood, M.D.E., Singh, S.S., Piovano, S., Ferreira, M., Johnson, J.E., Veitayaki, J., Kininmonth, S., Morris, C.W., 2018. Impacts of climate change on corals relevant to the Pacific Islands. In: Townhill, B., Buckley, P. (Eds.), Pacific Marine Climate Change Report Card. Commonwealth Marine Economies Programme, London, pp. 132-258.

Elsner, J.B., Kossin, J.P., Jagger, T.H., 2008. The increasing intensity of the strongest tropical cyclones. Nature 455, 92-95.

Etienne, S., Terry, J.P., 2012. Coral boulders, gravel tongues and sand sheets: features of coastal accretion and sediment nourishment by Cyclone Tomas (March 2010) on Taveuni Island, Fiji. Geomorphology 175, 54-65.

Farber, S., 1987. The value of coastal wetlands for protection of property against hurricane wind damage. J. Environ. Econ. Manag. 14 (2), 143-151.

Fisher, R., O'Leary, R.A., Low-Choy, S., Mengersen, K., Knowlton, N., Brainard, R.E., Caley, M.J., 2015. Species richness on coral reefs and the pursuit of convergent global estimates. Curr. Biol. 25, 500-505.

Folke, C., Pritchard Jr., L., Berkes, F., Colding, J., Svedin, U., 2007. The problem of fit between ecosystems and institutions: ten years later. Ecol. Soc. 12 (1), 30. https://www.ecologyandsociety.org/vol12/iss1/art30/main.html.

Ford, A.K., Eich, A., McAndrews, R.S., Mangubhai, S., Nugues, M.M., Bejarano, S., Moore, B.R., Rico, C., Wild, C., Ferse, S.C.A., 2018. Evaluation of coral reef management effectiveness using conventional versus resilience-based metrics. Ecol. Indicat. 85, 308-317.

Gelcich, S., Buckley, P., Pinnegar, J.K., Chilvers, J., Lorenzoni, I., Terry, G., et al., 2014 Public awareness, concerns, and priorities about anthropogenic impacts on marine environments. Proc. Natl. Acad. Sci. Unit. States Am. 111 (42), 15042-15047.

Guannel, G., Arkema, K., Ruggiero, P., Verutes, G., 2016. The power of three: coral reefs, seagrasses and mangroves protect coastal regions and increase their resilience. Plos One 11, 1-22.

Guillemot, N., Chabanet, P., Le Pape, O., 2010. Cyclone effects on coral reef habitats in New Caledonia (South Pacific). Coral Reefs 29, 445-453.

Hallock, P., Lidz, B.H., Cockey-Burkhard, E.M., Donnelly, K.B., 2003. Foraminifera as bioindicators in coral reef assessment and monitoring: the FORAM index. Environ. Monit. Assess. 81 (1-3), 221-238.

Harney, J.N., Grossman, E.E., Richmond, B.M., Fletcher, C.H.I., 2000. Age and composition of carbonate shoreface sediments, Kailua Bay, Oahu, Hawaii. Coral Reefs 19 (2), 141-154.

Harris, D.L., Rovere, A., Casella, E., Power, H., Canavesio, R., Collin, A., Parravicini, V., 2018. Coral reef structural complexity provides important coastal protection from waves under rising sea levels. Sci. Adv. 4 (2), 43-50.

Heiri, O., Lotter, A.F., Lemcke, G., 2001. Loss on ignition as a method for estimating organic and carbonate content in sediments: reproducibility and comparability of results. J. Paleolimnol. 25 (1), 101-110.
Hoffmann, T.C., 2002. Coral reef health and effects of socio-economic factors in Fiji and Cook Islands. Mar. Pollut. Bull. 44, 1281-1293.

IUCN, 2009. Navakavu Locally Managed Marine Area, Viti Levu Island, Fiji - Marine Protected Areas Case Studies. Protecting the oceans makes economic sense. International Union for Conservation of Nature, Washington, DC. https://www.iucn. org/downloads/marine_protected_areas_navakavu.pdf.

Janßen, A., Wizemann, A., Klicpera, A., Satari, D.Y., Westphal, H., Mann, T., 2017. Sediment composition and facies of coral reef islands in the spermonde Archipelago, Indonesia. Frontiers in Mar. Sci. 4, 144. https://www.frontiersin.org/articles/10 .3389/fmars.2017.00144/full.

Johnsson, M.J., Basu, A., 1993. Processes Controlling the Composition of Clastic Sediments, 284. Geological Society of America.

Kelleher, G., 1999. Guidelines for Marine Protected Areas. IUCN, Gland, Switzerland and Cambridge, UK.

Kench, P.S., Ford, M.R., Owen, S.D., 2018. Patterns of island change and persistence offer alternate adaptation pathways for atoll nations. Nat. Commun. 9, 605.

Knedler, K.E., Glasby, G.P., 1985. Geochemistry and mineralogy of marine sediments from the yasawa trough and braemar ridge, northwest of Viti Levu, Fiji. N. Z. J. Geol. Geophys. 28, 267-282.

Kostaschuk, R., Terry, J., Raj, R., 2003. Suspended sediment transport during tropicalcyclone floods in Fiji. Hydrol. Process. 17, 1149-1164.

Lal, R., Kininmonth, S., N'Yeurt, A.D.R., Riley, R.H., Rico, C., 2018. The effects of a stressed inshore urban reef on coral recruitment in Suva Harbour, Fiji. Ecology and Evolution 8 (23), 11842-11856.

Leão, Z.M.A.N., Kikuchi, R.K.P., Testa, V., Telles, M., Pereira, J., Dutra, L.X.C., Sampaio, C.L.S., 1999. First coral reef assessment in the southern hemisphere applying the AGRRA rapid protocol (Caramuanas Reef, Bahia, Brazil). In: International Conference on Scientific Aspects of Coral Reef Assessment, Monitoring and Restoration, pp. 122-123.

Lockwood, M., Davidson, J., Hockings, M., Haward, M., Kriwoken, L., 2012. Marine biodiversity conservation governance and management: regime requirements for global environmental change. Ocean Coast Manag. 69, 160-172.

Lovell, E.R., McLardy, C., 2008. Annotated Checklist of the CITES-Listed Corals of Fiji with Reference to Vanuatu, Tonga. Samoa and American Samoa.

Maata, M., Singh, S., 2008. Heavy metal pollution in Suva harbour sediments, Fiji. Environ. Chem. Lett. 6, 113-118.

Mangubhai, S., 2016. Impact of Tropical Cyclone Winston on Coral Reefs in the Vatu-I-Ra Seascape, Report No. 01/16, p. 27. Suva, Fiji.

Martin, L., Flexor, J.M., Villas-Boas, G.S., Bittencourt, A.C.S.P., Guimarães, M.M.M., 1979. Courbe de variation du niveau relatif de la mer au cours des 7000 dernières annés sur un secteur homogéne du littoral Brésilien (nord de Salvador-Bahia). 1978 International Symposium on coastal evolution in the Quaternary. São Paulo.

Martin, L., Dominguez, J.M., Bittencourt, A.C., 2003. Fluctuating Holocene sea levels in eastern and South Eastern Brazil: evidence from multiple fossil and geometric indicators. J. Coast Res. 101-124.

McKoy, H., Kennedy, D.M., Kench, P.S., 2010. Sand cay evolution on reef platforms, Mamanuca Islands, Fiji. Mar. Geol. 269, 61-73.

McLaren, P., Bowles, D., 1985. The effects of sediment transport on grain-size distributions. J. Sediment. Res. 55 (4), 457-470.

Milliman, J.D., 1974. Recent Sedimentary Carbonates Part 1 Marine Carbonates. Springer Berlin Heidelberg, Berlin, Heidelberg.

Ministry of Industry Trade and Tourism, 2018. Fijian Tourism 2021. MITT. Suva, Fijian Government. Avialable at. https://mitt.gov.fj/wp-content/uploads/2019/04/F T2021.pdf. (Accessed 13 August 2020).

Morris, C.W., Mackay, K., 2008. Status of the coral reefs in the South West Pacific: Fiji, New Caledonia, Samoa, Solomon Islands, Tuvalu and Vanuatu. Global Coral Reef Monitoring Network and Reef and Rainforest Centre.

Morris, M.J., Collen, J.D., Smith, R., Patterson, J.E., 2003. Sedimentology and geochemistry of reef flat sediments, Suva, Fiji: Implications for cement manufacture. Environ. Eng. Geosci. 9, 295-304.

Morrison, A.E., Cochrane, E.E., Rieth, T., Horrocks, M., 2018. Archaeological and sedimentological data indicate Lapita settlement on a newly formed coastal plain: Tavua Island, Mamanuca Group, Fiji. Holocene 28, 44-55.

Mosley, L.M., Aalbersberg, G.L.W., 2003. Nutrient levels in sea and river water along the coral coast of Viti Levu, Fiji. South Pac. J. Nat. Sci. 21 (1), 35-40.

Nott, J., Walsh, K., 2015. FactCheck: Is Global Warming Intensifying Cyclones in the Pacific? The Conversation Media Group Ltd.

Parker, G., Toro-Escobar, C.M., 2002. Equal mobility of gravel in streams: the remains of the day. Water Resour. Res. 38, 46-53.

Pascal, N., Seidl, A., 2013. Economic Benefits of Marine Protected Areas: Case Studies in Vanuatu and Fiji, South Pacific: Research Report. AFD/IUCN, French Framework Agreement by CRIOBE (EPHE/CNRS), Mooréa, French Polynesia, p. 160.

Perry, C.T., Kench, P.S., Smithers, S.G., Riegl, B.R., Gulliver, P., Daniells, J.J., 2017. Terrigenous sediment-dominated reef platform infilling: an unexpected precursor to reef island formation and a test of the reef platform size-island age model in the Pacific. Coral Reefs 36, 1013-1021.

Quinn, N.J., Kojis, B.L., 2008. Variation in coral recruitment on Fijian reefs. In: Proceedings of the 11th International Coral Reef Symposium, 14.

Roy, P., 1988. Coastal and nearshore geology of savusavu bay, Vanua Levu, Fiji. In: Committee for Co-ordination of Joint Prospecting for Mineral Resources in South Pacific Offshore Areas, CCOP/SOPAC, 60, p. 35.

Shah, S.B., 2008. Study of Heavy Metal Accumulation in Scleractinian Corals of Viti Levu, Fiji Islands. University of the South Pacific Masters thesis.

Sharma, A.D., 2007. A Study of the Benthic Foraminifera of Laucala Bay, with Special Focus on Marginopora Vertebralis. Master's Thesis. School of Marine Studies, The 
University of the South Pacific, Suva. https://www.usp.ac.fj/fileadmin/files/schools /spas/macs/Research_and_Graduate_Affairs/2007/Ashishika_D._Sharma.PDF.

Sloan, J., Chand, K., 2016. An analysis of property rights in the Fijian qoliqoli. Mar. Pol. $72,76-81$.

Smith, J.E., Brainard, R., Carter, A., Grillo, S., Edwards, C., Harris, J., Lewis, L., Obura, D., Rohwer, F., Sala, E., Vroom, P.S., Sandin, S., 2016. Re-evaluating the health of coral reef communities: baselines and evidence for human impacts across the central Pacific. Proceedings. Biological sciences 283 (1822), 20151985. https:// doi.org/10.1098/rspb.2015.1985.

Spalding, M.D., Ravilious, C., Green, E.P., 2001. World Atlas of Coral Reefs. In: Prepared at the UNEP World Conservation Monitoring Cente. University of California Press, Berkeley, USA, p. 424.

Srinivasan, M.S., Kennett, J.P., 1981. Neogene planktonic foraminiferal biostratigraphy and evolution: equatorial to subantarctic, South Pacific. Mar. Micropaleontol. 6, 499-533.

Stanley, J.D., 2007. Kaulonia, southern Italy: Calabrian arc tectonics inducing Holocene coastline shifts. Méditerranée. J. Mediterranean Geography 108, 7-15.

Stocker, L., Wood, D., 2012. Sustainable Coastal Management and Climate Adaptation: Global Lessons from Regional Approaches in Australia. Csiro Publishing.

Sykes, H.R., Lovell, E.R., 2009. A cause for optimism: identification of threats and resiliency on Pacific reefs through establishment of a long term reef monitoring network in Fiji: the Fiji Coral Reef Monitoring Network (FCRMN). In: Proceedings of the 11th Pacific Science Inter-congress and 2nd Symposium on French Research in the Pacific.

Sykes, H., Morris, C., 2009. Status of Coral Reefs in the Fiji Islands, 2007. South-West Pacific Status of Coral Reefs Report, 1.

Taloiburi, E.J., 2009. An Evaluation of the Effects of Wastewater Treatment Initiatives on Water Quality in Coastal Waters along the Coral Coast, Southwest Viti Levu, Fiji Islands. Doctoral dissertation. The University of the South Pacific. http://digilib.lib rary.usp.ac.fj/gsdl/collect/usplibr1/index/assoc/HASH5faa.dir/doc.pdf.

Tawake, A., Tuivanuavou, S., 2004. Community involvement in the implementation of ocean policies: the Fiji locally managed marine areas (FLMMAs) network. SPC Traditional Marine Resource Management and Knowledge Information Bulletin 17.
Techera, E.J., Troniak, S., 2009. Marine Protected Areas Policy and Legislation Gap Analysis: Fiji Islands. IUCN Regional Office for Oceania, Suva, Fiji.

Terry, J.P., Lal, R., Garimella, S., 2008. An examination of vertical accretion of floodplain sediments in the Labasa river sugarcane belt of Northern Fiji: rates, influences and contributing processes. Geogr. Res. 46, 399-412.

Tyllianakis, E., Grilli, G., Gibson, D., Ferrini, S., Conejo-Watt, H., Luisetti, T., 2019. Policy options to achieve culturally-aware and environmentally-sustainable tourism in Fiji. Mar. Pollut. Bull. 148, 107-115.

Varea, R., Piovano, S., Ferreira, M., 2020. Knowledge gaps in ecotoxicology studies of marine environments in Pacific Island Countries and Territories - a systematic review. Mar. Pollut. Bull. 156, 111264.

Veitayaki, J., Aalbersberg, B., Tawake, A., Rupeni, E., Tabunakawai, K., 2004. Mainstreaming Resource Conservation: the Fiji Locally Managed Marine Area Network and its Influence on National Policy Development.

Veitayaki, J., Ledua, E., 2016. Policy options for coastal and tuna fisheries in the Pacific Islands: sustaining resources on the same side of the same coin. Fisheries in the Pacific Islands the Challenges of Governance and Sustainability. E. Fache and S. Pauwels Marseille. Pacific-Credo Publications, France, pp. 255-287. https://openre search-repository.anu.edu.au/bitstream/1885/40990/3/rmap_wp42.pdf.

Wood, E., Malsch, K., Miller, J., 2012. July). International trade in hard corals: review of management, sustainability and trends. In: Proceedings of the 12th International Coral Reef Symposium, Cairns, Australia, pp. 9-13.

Wooldridge, S.A., Heron, S.F., Brodie, J.E., Done, T.J., Masiri, I., Hinrichs, S., 2017. Excess seawater nutrients, enlarged algal symbiont densities and bleaching sensitive reef locations: 2. A regional-scale predictive model for the Great Barrier Reef, Australia. Mar. Pollut. Bull. 114 (1), 343-354.

Zann, L.P., 1994. The status of coral reefs in south western Pacific islands. Mar. Pollut. Bull. 29 (1), 52-61.

Zill, J.A., Gil, M.A., Osenberg, C.W., 2017. When environmental factors become stressors: interactive effects of vermetid gastropods and sedimentation on corals. Biol. Lett. 13 (3) https://doi.org/10.1098/rsbl.2016.0957, 20160957. 